\title{
Analytical Assessment of Power of Composite Flash Geothermal Systems ${ }^{2}$
}

\begin{abstract}
Analytical formulas make it possible to observe thermodynamic processes without using advanced numerical procedures, as the relationships between the physical parameters become clearly visible. While less accurate, these formulas enable students at the academic research level to quickly and easily model the phenomena using simple calculation programs.

For a single-flash system, the linear approximation makes it possible to obtain the expression for the optimum flash temperature and maximal specific power in the assumed temperature interval of geothermal fluid $\left(100-250^{\circ} \mathrm{C}\right)$.

These formulas were presented in the author's previous works. Now, this procedure was used in example analyses for double-flash, combination single \& second, and combination single \& ORC systems. It was shown that, in the assumed temperature interval of geothermal fluid, the percentage of the additional power of composite-flash geothermal systems is almost a linear function of geothermal fluid temperature as related to a single-flash plant and that the single-flash \& ORC cycle gives the highest additional specific power.
\end{abstract}

Keywords: geothermal, flash system, optimal specific power, composite unit analysis

Received: 22 February 2019; accepted: 28 May 2019

1 AGH University of Science and Technology, Faculty of Mining Surveying and Environmental Engineering, Department of Management and Protection of Environmental, Krakow, Poland; email: Antoni.barbacki@agh.edu.pl ORCID ID: https://orcid.org/0000-0002-1967-406X

2 The article was prepared as part of the AGH UST statutory research No. 11.11.150.008 


\section{Introduction}

In 1996, electricity was being produced from geothermal sources in 21 countries (with a total production of $38 \mathrm{TWh} / \mathrm{a}$ ), and geothermal energy had the largest installed electrical capacity (61\%) and electricity production (81\%) among the "new renewables" (geothermal, solar, wind, and tidal energy) [1]. In 2003, the total global production exceeded $50 \mathrm{TWh} / \mathrm{a}$ [2], and in 2010, 24 countries were already producing about $70 \mathrm{TWh} / \mathrm{a}$ [3]; currently, the combined global power of geothermal power plants is nearing $12 \mathrm{GW}$. The most common energy conversion systems that can be used for the generation of electricity from geothermal energy are single flash and double flash. The total installed capacity in the world for these types of power plants are single-flash plants (42.2\%) and double-flash plants (23\%) [4]. A method for expressing the efficiency and specific power of a flash geothermal plant as a function of flash temperature was examined by Ryley [5]. Issues referring to geothermal flash plants were presented in papers by Swandaru and Palsson [6], Kanoglu, Dincer, and Rosen [7], and DiPippo [8], among others. In Europe, single- and double-flash installations operate in Iceland, Italy, and Turkey, where the exergy of geothermal resources is sufficiently high [9]. In other parts of the world, these operate mainly in volcanic areas of the Pacific Ring of Fire and on tectonic plate boundaries.

The analyses were intended to estimate the optimal parameters required for the flashing process to achieve the maximum power for a hypothetical geothermal plant. The problem of maximizing the power output of a single-flash plant is a well-known issue and involves identifying the value of the optimal flash temperature at which the maximum of the product of the steam mass flow rate and the expansion enthalpy is obtained (for a given wellhead temperature $t_{0}$ and condensation temperature $t_{2}$ ) [10]. In reality, the power of such systems is further limited by a number of other phenomena apart from thermodynamic ones. The net power output of a flash system is determined by, inter alia, the plant's own consumption and machinery efficiency as well as the scaling and clogging processes [11-13]. Owing to the theoretical nature of the issues presented, these factors have not been accounted for in this paper.

\section{Power Estimation of Single-Flash Plant}

An analysis of single-flash systems was presented in an earlier author's article [10]. The main results of the work are summarized below.

A scheme for a single-flash geothermal plant is presented in Figure 1. Flash steam plants are used to generate power from liquid-dominated resources that are hot enough to flash the water to steam in surface equipment. In the analysis presented, a saturated thermal water (mostly two-phase fluids) at the wellhead, an isenthalpic flash process, and a maximum thermal water temperature $\left(t_{0}\right)$ of up to $250^{\circ} \mathrm{C}$ are assumed. 


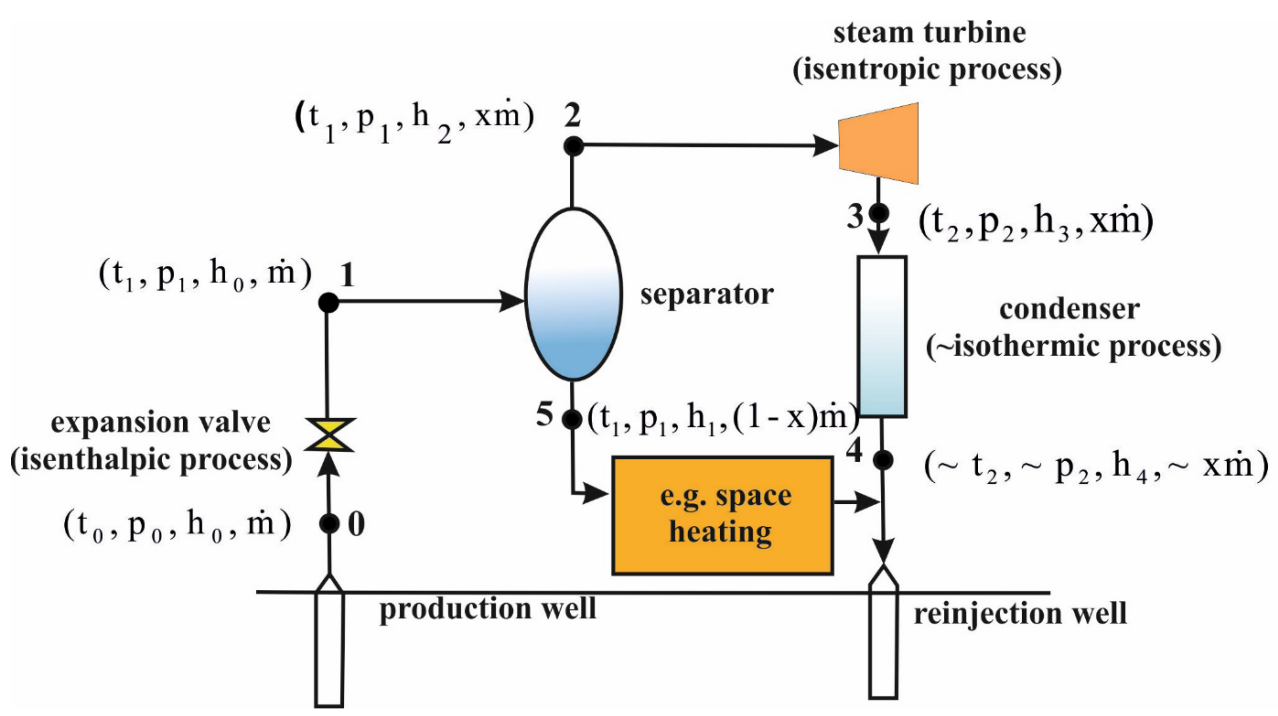

Fig. 1. Scheme of single-flash geothermal power plant (characteristic points and symbols are as found in Figure 2: $t$ - temperature, $p$-pressure, $h$-specific enthalpy, $\dot{m}$-mass flow rate, $x$-dryness [steam fraction])

In a conventional steam turbine, the geothermal power $(W)$ is the change in the isentropic enthalpy, taking isentropic turbine efficiency and mass flow rate into account:

$$
W=\eta \dot{m}\left(h_{2}-h_{3}\right)
$$

where:

$h_{2}$ - specific enthalpy of steam entering turbine,

$h_{3}$ - specific enthalpy of fluid exiting turbine (assuming isentropic turbine),

$\eta$ - turbine efficiency (usually $0.75-0.85$ ),

$\dot{m}$ - total mass flow rate from well (in most cases also depending on flash temperature).

In a flash system, the mass flow rate entering the turbine (Fig. 1) is $x \dot{m}$; thus, the specific power of the turbine is as follows according to (1):

$$
W=\eta x\left(h_{2}-h_{3}\right)
$$

where:

$h_{2}$ - specific enthalpy of saturated steam (Point 2, Fig. 2) at flash temperature $t_{1}$

$h_{3}$ - specific enthalpy of fluid exiting turbine at condensation temperature $t_{2}$ (Point 3, Fig. 2),

$x$ - steam fraction (at Point 1, Fig. 2). 
Taking into account that $x=f\left(t_{1}\right)$ and $h_{1}=f\left(t_{1}\right)$ :

$$
x\left(t_{1}\right)=\frac{h_{0}-h_{1}\left(t_{1}\right)}{R_{0}+h_{0}-h_{1}\left(t_{1}\right)}
$$

where (see Fig. 2):

$R_{1}$ - latent heat for flash temperature $t_{1}$ and pressure $p_{1^{\prime}}$

$R_{0}$ - latent heat for thermal water temperature $t_{0}$ and pressure $p_{0^{\prime}}$

$h_{0}$ - specific enthalpy of saturated thermal water at Point 0 ,

$h_{1}$ - specific enthalpy of saturated water at flash temperature $t_{1}$.

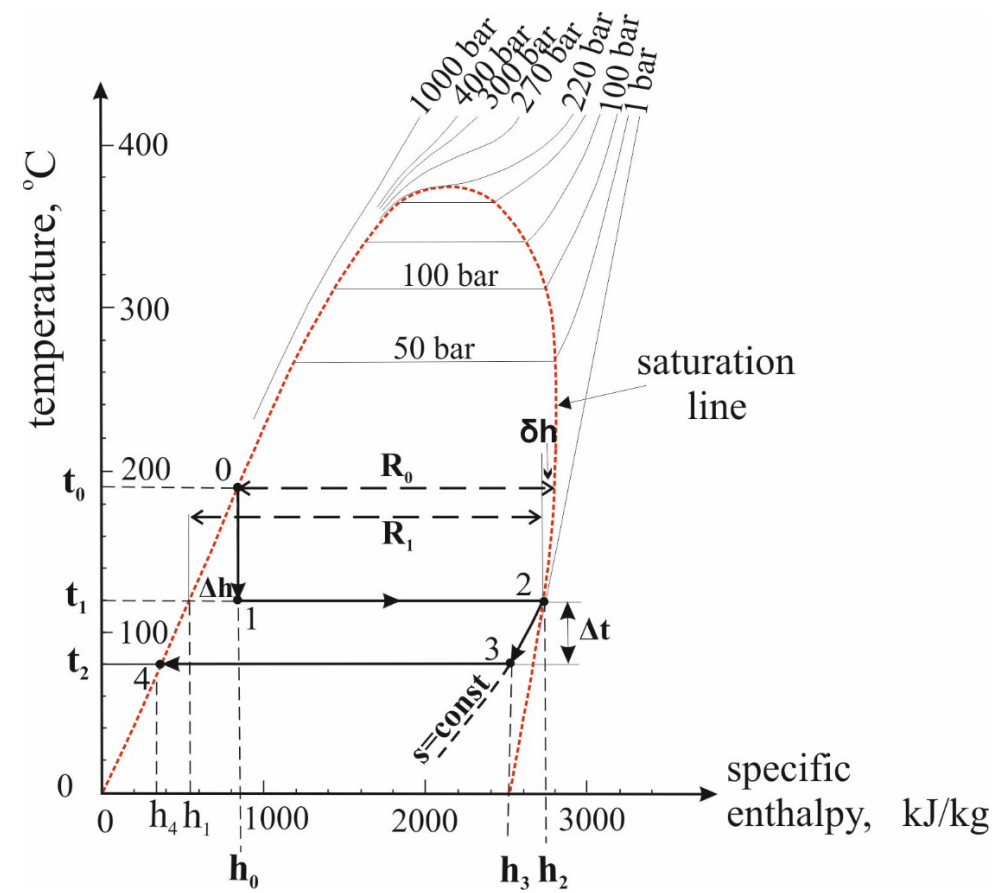

Fig. 2. Single-flash cycle on temperature - enthalpy diagram $(t-h)$

Analyses have shown that the maximal value of the specific power in Expression (2) can only occur at a strictly defined parameter of $t_{1}$ [10]:

$$
w\left(t_{1}\right)=\eta \frac{h_{0}-h_{1}\left(t_{1}\right)}{R_{0}+h_{0}-h_{1}\left(t_{1}\right)}\left(t_{1}-t_{2}\right)\left(7.62-0.0133 t_{1}\right)
$$

The unit of $w\left(t_{1}\right)$ is $[\mathrm{kW} / \mathrm{kg} / \mathrm{s}]$ if the values of $\left(7.62-0.0133 t_{1}\right)$ are expressed in $[\mathrm{kJ} /(\mathrm{kg} \cdot \mathrm{K})]$ or $\left[\mathrm{kJ} /\left(\mathrm{kg} \cdot{ }^{\circ} \mathrm{C}\right)\right]$, the value of $t_{1}-t_{2}$ in $\left[{ }^{\circ} \mathrm{C}\right]$, and the values of $h_{0^{\prime}} h_{1^{\prime}}$ and $R_{0}$ in $[\mathrm{kJ} / \mathrm{kg}]$. 
Function $w\left(t_{1}\right)$ is practically a symmetrical "parabola"; thus, the maximum power occurs for the value of $t_{1}$ closest to the arithmetic average of $t_{0}$ and $t_{2}$ :

$$
t_{1}^{\mathrm{opt}} \approx \frac{t_{0}+t_{2}}{2}
$$

Despite the fact that estimation $w\left(t_{1}\right)$ gives some errors, it allows for a quick and simple assessment of the maximal (optimal) power of a flash geothermal plant $\left(w_{\max }\right)$

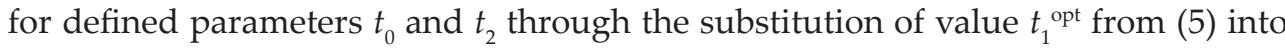
Expression (4):

$$
w_{\max }\left(t_{1}^{\mathrm{opt}}\right)=\eta \frac{h_{0}-h_{1}\left(t_{1}^{\mathrm{opt}}\right)}{R_{0}+h_{0}-h_{1}\left(t_{1}^{\mathrm{opt}}\right)}\left(t_{1}^{\mathrm{opt}}-t_{2}\right)\left(7.62-0.0133 t_{1}^{\mathrm{opt}}\right)
$$

According to Expression (6), the values of maximal specific power depend only on the value of condensation temperature $t_{2}$ for a given temperature of thermal fluid $t_{0}$ since $t_{1}^{\text {opt }}=\left(t_{0}+t_{2}\right) / 2=f\left(t_{2}, t_{0}\right)$.

The example of the calculation of maximum specific power according to Formula (6) for the assumed parameters of thermal fluid $t_{0}=200^{\circ} \mathrm{C}$ and assumed condensation temperature $t_{2}=80^{\circ} \mathrm{C}$ and $\eta=0.8$ gives the following results: $t_{1}^{\text {opt }}=140^{\circ} \mathrm{C}$; $w_{\max }=33 \mathrm{~kW} / \mathrm{kg} / \mathrm{s}$.

\section{Double-Flash Plant}

To produce additional power output, the waste liquid could be utilized by using a double-flash or binary unit.

Figure 3a shows a simplified schematic diagram of a double-flash plant. The equipment of the plant includes a high-pressure (HP) and low-pressure (LP) separator, a high-pressure (HPT) and low-pressure turbine (LPT), a condenser, and a cooling tower with water pumps. The system uses a two-stage separation of the fluid. At first, the geothermal fluid from the well is flashed, the steam and brine are separated in an HP separator, and high-pressure steam is directed to a high-pressure turbine (HPT). The separated brine (still with high enthalpy) is directed to a flash valve and (after flashing) to an LP separator; this produces additional steam. Steam exiting the HPT turbine is mixed with this additional steam and then directed to the LPT turbine, generating extra power. The remaining brine from the LP separator is pumped to the reinjection well. For simplicity, only two thermodynamic parameters (pressure and mass flow rate) are presented for individual points of the diagram in Figure 3a. Assuming a value of $\dot{m}=1 \mathrm{~kg} / \mathrm{s}$ at point (0), the mass flow rates at subsequent points on the diagram are represented by a change in the values of steam fractions $(x)$. Therefore, the mass flow rate at the exit from the HPT turbine has a value of $x_{1}[\mathrm{~kg} / \mathrm{s}]$ and that at the exit of the LP separator has a value of $\left(1-x_{1}\right) x_{2}[\mathrm{~kg} / \mathrm{s}]$. 
a)

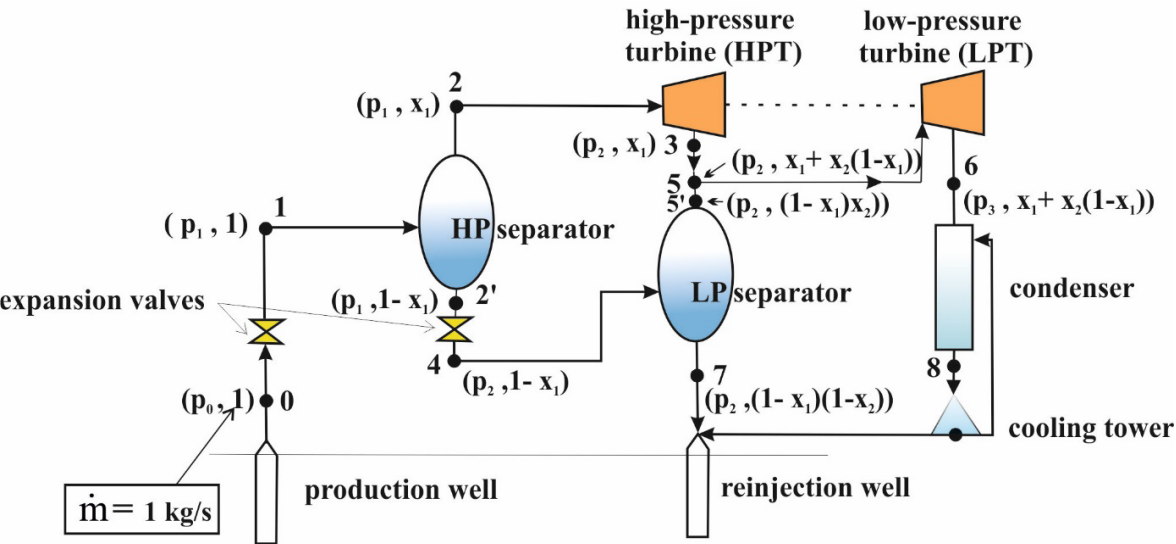

b)

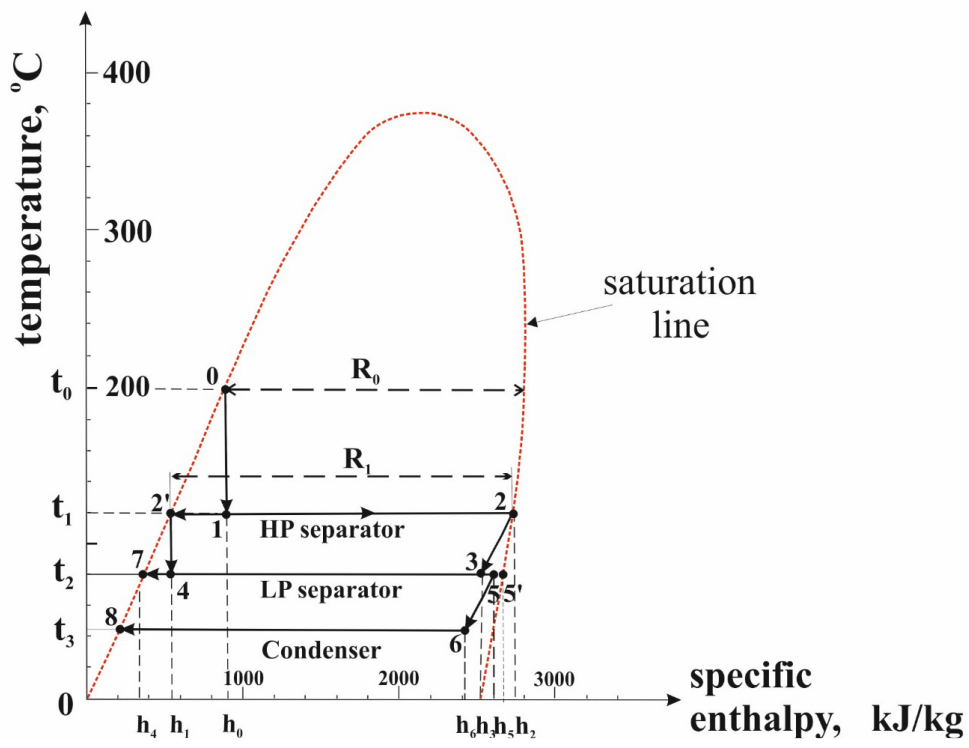

Fig. 3. Schematic diagram of double-flash geothermal plant (pressure and mass flow rate values provided for characteristic points assuming unit flow value at wellhead) (a); temperature-enthalpy diagram for double-flash system (b)

In Figure 3b, a temperature-enthalpy diagram is shown, which demonstrates the nature of the thermodynamic phenomena that accompany the operation of a double-flash system. Analogously to Formula (4), this is written in the following simple form:

$$
w\left(t_{1}\right)=\eta x_{1}\left(t_{1}-t_{2}\right)\left(7.62-0.0133 t_{1}\right)
$$

and taking into account the value of the steam flow rate at Point (5) of the diagram in Figure 3a, the specific power of the LPT turbine for various values of parameter $t_{2}$ 
and for the established value of condensation temperature $t_{3}$ can be expressed by the following formula:

$$
w^{\mathrm{LPT}}\left(t_{2}\right)=\eta^{\mathrm{LPT}}\left(x_{1}+x_{2}-x_{1} x_{2}\right)\left(t_{2}-t_{3}\right)\left(7.62-0.0133 t_{2}\right)
$$

where, according to Figure $3 b$ and Expression (3), $x_{2}=f\left(t_{2}\right)$ :

$$
x_{2}=\frac{h_{1}\left(t_{1}^{\mathrm{opt}}\right)-h_{4}\left(t_{2}\right)}{R_{1}\left(t_{1}^{\mathrm{opt}}\right)+h_{1}\left(t_{1}^{\mathrm{opt}}\right)-h_{4}\left(t_{2}\right)}
$$

Thus, the value of $x_{2}$ can be determined from thermodynamic tables (e.g., the CoolPack database) by reading $R_{1}$ for a fixed temperature $t_{1}^{\text {opt }}$ (similar to $h_{1}\left(t_{1}^{\text {opt }}\right)-h_{4}\left(t_{2}\right)$ ) by using the enthalpy values for saturated water obtained from the tables for temperatures $t_{1}^{\text {opt }}$ and $t_{2}$.

The problem is the estimation of the maximal specific power of a double-flash geothermal plant as a function of temperatures $t_{1}$ and $t_{2}$, where the established parameters are $\eta, t_{0^{\prime}}$ and $t_{3}$.

In the example calculations presented below, we limit ourselves to the case where the HPT turbine operates under optimal values $\left(t_{1}{ }^{\text {opt }}\right.$ for established temperature $t_{0}$ and for variable values of LP separator temperature $t_{2}$ ). For such conditions where $t_{1}^{\text {opt }}=f\left(t_{2}\right)$, the expression for the optimal (maximal) specific power of the HPT turbine for various values of $t_{2}$ takes the following form:

$$
w_{\mathrm{opt}}^{\mathrm{HPT}}\left(t_{2}\right)=\eta^{\mathrm{HPT}} x_{1}\left(t_{1}^{\mathrm{opt}}-t_{2}\right)\left(7.62-0.0133 t_{1}^{\mathrm{opt}}\right)
$$

where $t_{1}^{\text {opt }}=f\left(t_{2}\right)=\left(t_{0}+t_{2}\right) / 2$, and where $x_{1}=f\left(t_{2}\right)$ :

$$
x_{1}=\frac{h_{0}-h_{1}\left(t_{1}^{\mathrm{opt}}\right)}{R_{0}+h_{0}-h_{1}\left(t_{1}^{\mathrm{opt}}\right)}
$$

Figure 4 shows the parameters and calculation results for the double-flash system model using thermal fluid at a temperature of $200^{\circ} \mathrm{C}$ for variable LP separator temperatures $t_{2}$ and for a fixed condensation temperature of $t_{3}=80^{\circ} \mathrm{C}$.

In the model, a simplifying assumption was made that the isentropic efficiencies of both turbines are equal (amounting to $\eta^{\mathrm{HPT}}=\eta^{\mathrm{LPT}}=0.8$ ). The example shows the impact of temperature $t_{2}$ on the $w_{\mathrm{opt}}^{\mathrm{HPT}}$ and $w^{\mathrm{LPT}}$ power values at a constant value of condensation temperature $t_{3}$.

From the diagram in Figure 4, we can see the following for that established conditions of operation:

- maximum $w_{\mathrm{opt}}^{\mathrm{HPT}}$ power $=$ maximum $w^{\mathrm{LPT}}$ power $\approx 33 \mathrm{~kW} / \mathrm{kg} / \mathrm{s}$;

- the maximum total power of a double-flash system $(\sim 45 \mathrm{~kW} / \mathrm{kg} / \mathrm{s})$ is ca. $37 \%$ higher than the maximum power of a single-flash system $(\sim 33 \mathrm{~kW} / \mathrm{kg} / \mathrm{s})$;

- the maximum total system power of $\sim 45,4 \mathrm{~kW} / \mathrm{kg} / \mathrm{s}$ is achieved close to the value of $t_{2}^{\mathrm{opt}}=120^{\circ} \mathrm{C}$, and for turbine HPT: $t_{1}^{\mathrm{opt}}=1 / 2\left(t_{0}+t_{2}^{\mathrm{opt}}\right)=160^{\circ} \mathrm{C}$. 


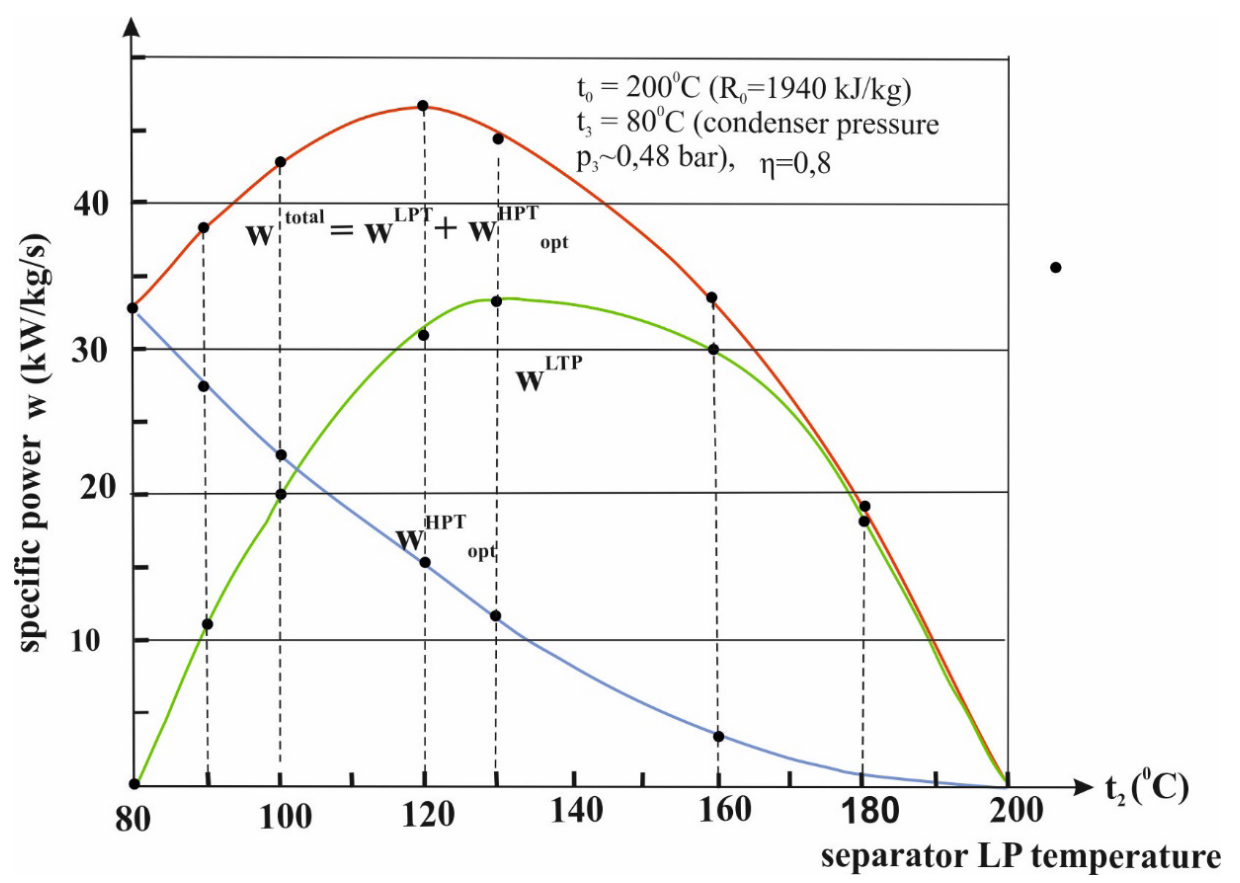

Fig. 4. Plots of specific power for double-flash geothermal cycles $(w)$ as function of LP separator temperature $\left(t_{2}\right)$ for fixed temperature of geothermal fluids $t_{0}=200^{\circ} \mathrm{C}$ and condensation temperature $t_{3}=80^{\circ} \mathrm{C}$

An analysis of the geometry of the power functions made for the different values of $t_{3}$ and $t_{0}$ (for $t_{0}$ ranging from $100^{\circ} \mathrm{C}$ to $250^{\circ} \mathrm{C}$ ) allowed us to determine the approximate value of the $t_{2}{ }^{\text {opt }}$ parameter:

$$
t_{2}^{\text {opt }} \approx 1 / 2\left(t_{0}+t_{3}\right)-0.1 t_{0}
$$

Thus, for variable resource temperatures $t_{0}$ and variable $t_{3^{\prime}}$ the value of the maximal total power can be simply calculated by a substitution of $t_{2}=t_{2}^{\text {opt }}$, and $t_{1}{ }^{\mathrm{opt}}=1 / 2\left(t_{0}+t_{2}{ }^{\mathrm{opt}}\right)$ to Expressions (8)-(11).

\section{Combination Single- and Second-Flash}

Also, to increase the power output of the existing single-flash plant, a separate second-flash plant can be considered as the bottoming unit. Figure 5a shows a simplified diagram of a combination single- and second-flash plant. Meanwhile, Figure $5 b$ shows a temperature-enthalpy diagram that demonstrates the nature of the thermodynamic phenomena that accompany the operation of a combination singleand second-flash system. 
a)

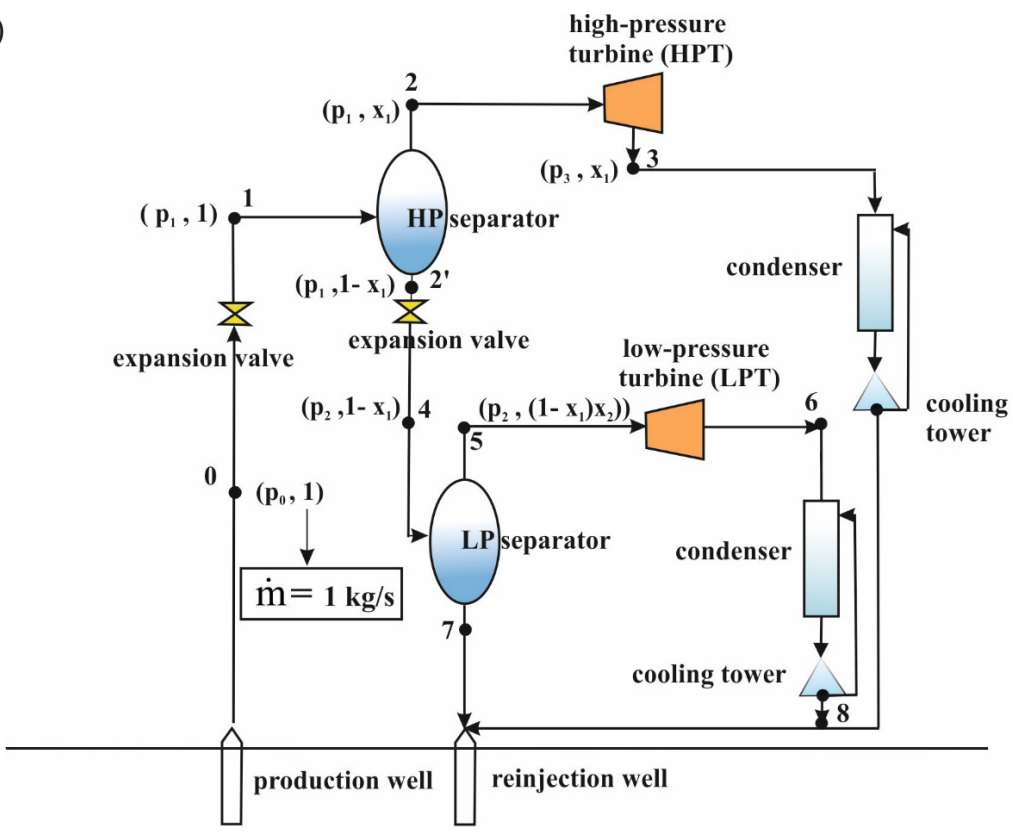

b)

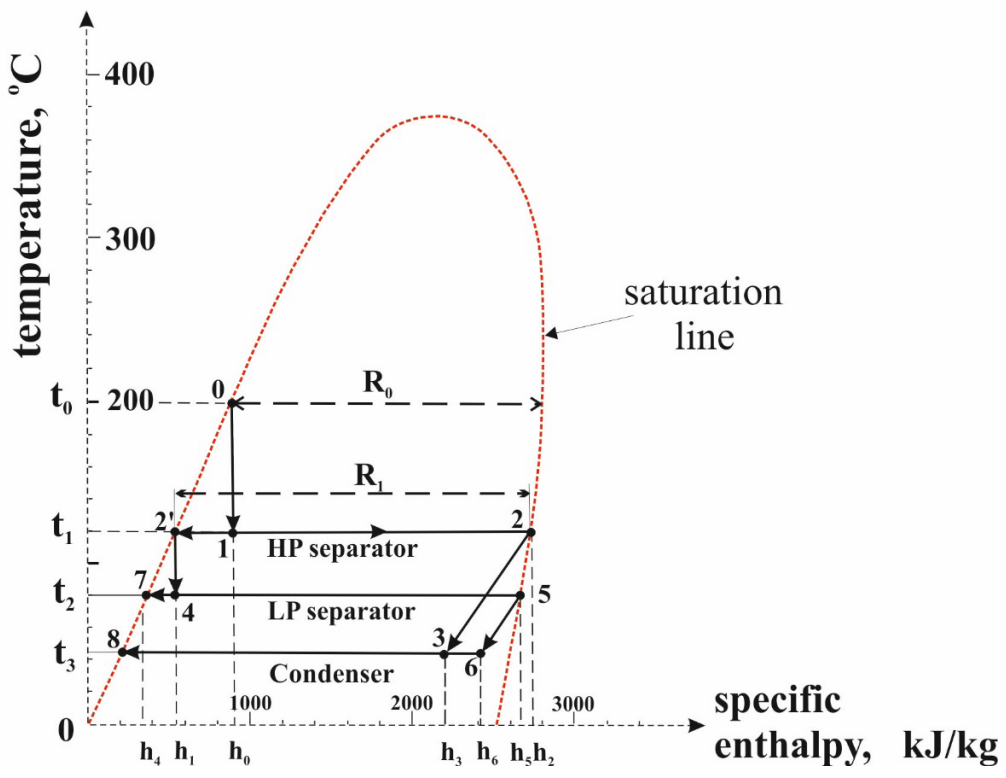

Fig. 5. Simplified diagram of combination single- and second-flash plant (a); temperature-enthalpy diagram for combination single- and second-flash system (b)

Let us consider the same model for the temperature of geothermal resources $t_{0}$ and condensation temperature $t_{3}$ as well as for the operating conditions of turbines $\left(t_{1}=t_{1}^{\mathrm{opt}}, \eta=\eta^{\mathrm{HPT}}=\eta^{\mathrm{LPT}}\right)$. 
Equation (4) for the HP turbine can be expressed by the following formula:

$$
w_{\mathrm{opt}}^{\mathrm{HPT}}\left(t_{1}^{\mathrm{opt}}\right)=\eta x_{1}\left(t_{1}^{\mathrm{opt}}-t_{3}\right)\left(7.62-0.0133 t_{1}^{\mathrm{opt}}\right)
$$

and for the LP turbine:

$$
w_{\mathrm{opt}}^{\mathrm{LPT}}\left(t_{2}^{\mathrm{opt}}\right)=\eta\left(1-x_{1}\right) x_{2}\left(t_{2}^{\mathrm{opt}}-t_{3}\right)\left(7.62-0.0133 t_{2}^{\mathrm{opt}}\right)
$$

where $t_{1}^{\text {opt }}=1 / 2\left(\mathrm{t}_{0}+\mathrm{t}_{3}\right), t_{2}^{\mathrm{opt}}=1 / 2\left(t_{1}^{\mathrm{opt}}+t_{3}\right), x_{1}$ as in Expression (11) and $x_{2}$ as in Expression (9) for $t_{2}=t_{2}^{\text {opt }}$.

Thus, the values of $w_{\mathrm{opt}}{ }_{\text {HPT }}$ are the same as for a single-flash plant; however, due to the lack of using the stream exiting the HP turbine, the values of $w_{\text {opt }}{ }^{\text {LPT }}$ are lower. In the case of the example shown above, the results of the calculation are as follows:

for $t_{0}=200^{\circ} \mathrm{C}$ and $t_{3}=80^{\circ} \mathrm{C}: w_{\text {opt }}^{\text {HPT }}=33.0 \mathrm{~kW} / \mathrm{kg} / \mathrm{s}, w^{\mathrm{LPT}}=7.3 \mathrm{~kW} / \mathrm{kg} / \mathrm{s}$, $w^{\text {total }}=40.3 \mathrm{~kW} / \mathrm{kg} / \mathrm{s}$, and the percentage of additional power is ca. $22 \%$.

\section{Combination Single-Flash and ORC Plant}

Another possibility for generating more power from a single-flash plant is by using an ORC unit. A simplified diagram of a combination single-flash and ORC plant is shown in Figure 6.

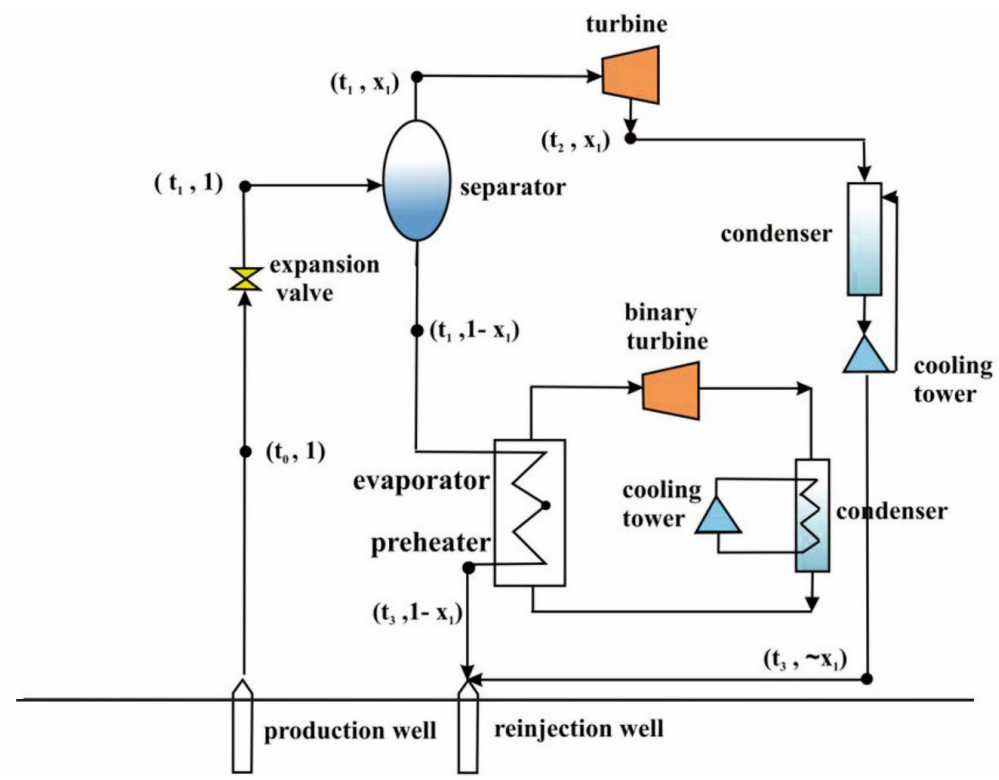

Fig. 6. Simplified diagram of combination single-flash and ORC plant 
Considering the same model, the optimal power of steam turbine can be expressed by Formula (13). For a binary unit, the specific power $(w)$ calculation utilizes the Second Law of Thermodynamics:

$$
w=\eta^{\text {bin }} \Delta q\left(1-\frac{T_{3}}{T}\right)
$$

where

$$
\begin{aligned}
\Delta q=c\left(T-T_{3}\right) & - \text { unitary heat input to binary cycle }[\mathrm{kJ} / \mathrm{kg}] \\
T & - \text { absolute temperature at inlet of evaporator, } \\
T_{3}- & \text { absolute temperature of rejection, } \\
c \text { - average specific heat of geothermal fluid in interval } & \left(T-T_{0}\right)[\mathrm{kJ} /(\mathrm{kg} \cdot \mathrm{K})], \\
\eta^{\text {bin }}- & \text { utilization efficiency factor. }
\end{aligned}
$$

The unit of $w$ is $[\mathrm{kW} / \mathrm{kg} / \mathrm{s}]$ if the value of $\Delta q$ is expressed in $[\mathrm{kJ} / \mathrm{kg}]$. In the case of the considered example, a simplifying assumption was made that the temperature of rejection is equal to the condensation temperature $\left(T_{3}=t_{3}+273^{\circ} \mathrm{C}\right)$ (Fig. 6), and $T=\left(t_{1}^{\text {opt }}+273^{\circ} \mathrm{C}\right), t_{1}^{\mathrm{opt}}=1 / 2\left(t_{0}+t_{3}\right), c=\left[h\left(t_{1}^{\mathrm{opt}}\right)-h\left(t_{3}\right)\right] /\left(t_{1}^{\mathrm{opt}}-t_{3}\right)$. As the mass flow rate is $\left(1-x_{1}\right)$ at the inlet of the evaporator, and for binary facilities $\eta^{\text {bin }} \approx 0.45$, Expression (15) takes the following form:

$$
w^{\text {bin }}=0.45 c\left(t_{1}^{\mathrm{opt}}-t_{3}\right)\left(1-x_{1}\right)\left[1-\frac{\left(t_{3}+273\right)}{\left(t_{1}^{\mathrm{opt}}+273\right)}\right]
$$

where $x_{1}$ - as in Expression (11).

Taking the total conversion efficiency factor for binary plants into account, the simplified formula is trivial; namely, $w^{\text {bin }} \approx 7 \% \Delta q$.

As in the case of the example shown above, the maximum power of steam turbine $\mathrm{w}^{\mathrm{st}}$ is the same as for the single-flash plant $(33 \mathrm{~kW} / \mathrm{kg} / \mathrm{s})$; the results of the calculation are as follows:

for $t_{0}=200^{\circ} \mathrm{C}$ and $t_{3}=80^{\circ} \mathrm{C}: w^{\text {st }}=33.0 \mathrm{~kW} / \mathrm{kg} / \mathrm{s}, w^{\text {bin }}=15.0 \mathrm{~kW} / \mathrm{kg} / \mathrm{s}$, $w^{\text {total }}=48.0 \mathrm{~kW} / \mathrm{kg} / \mathrm{s}$, and the percentage of additional power is ca. $45 \%$.

\section{Conclusions}

The procedure of the analytical formulae for the flash cycle makes it possible to analyze and observe the mutual relationships between the individual thermodynamic parameters. Where advanced numerical methods are used, it is usually only 
a graph that allows us to learn and understand the processes that take place. From an academic point of view, an analytical formula is more thermodynamically readable, thus allowing us to perform useful modeling using simply calculations. The errors produced by the applied procedure are mainly the result of the errors in the estimation of the $x$ parameter. Thus, we limit ourselves to the case where the range of temperature $t_{0}$ is $100-250^{\circ} \mathrm{C}$ and where function $(t-h)$ has sufficient linearity in the analyses presented above.

Despite some errors, the results of this study can be used as a simple way to determine the specific power output from flash plants. The question is which type of bottoming unit can produce the maximum power output when a geothermal field has a given temperature.

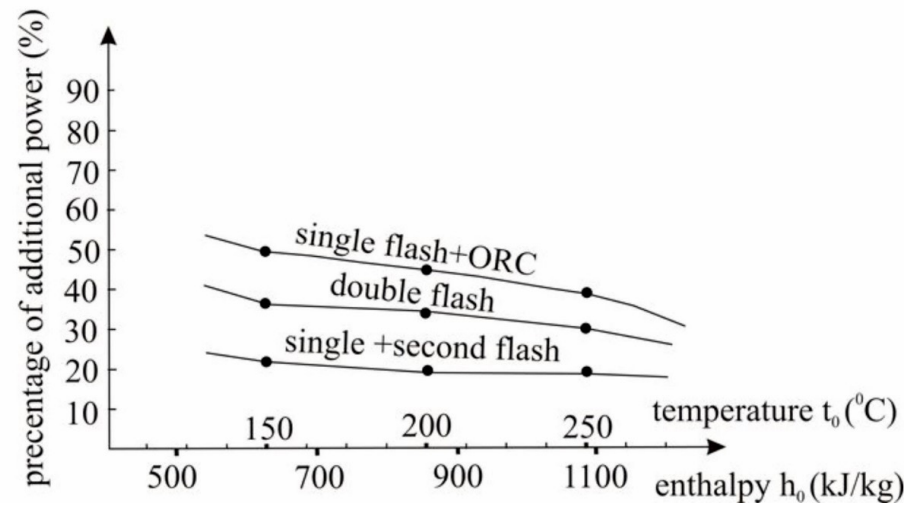

Fig. 7. Percentage of additional specific power output of combination plants vs. geothermal resource temperature $t_{0}$

From Figure 7 (which shows the results of the calculations of various geothermal fluids temperatures), we can see that, for temperature $t_{0}$ ranging from 150 to $250^{\circ} \mathrm{C}$, the percentage of the additional power is almost a linear function of $t_{0^{\prime}}$ and the single-flash \& ORC cycle gives the highest additional specific power as compared to a single-flash plant. The results are close to the results obtained in studies based on advanced professional programs [6] that take a number of technical and economic conditions into account (e.g., estimation of auxiliary power, corrosion, scaling, and so on).

\section{References}

[1] Fridleifsson I.B.: Present status and potential role of geothermal energy in the world. Renewable Energy, vol. 8, no. 1-4, 1996, pp. 34-39.

[2] Fridleifsson I.B.: Status of geothermal energy amongst the world's energy sources. Geothermics, vol. 32, no. 4, 2003, pp. 379-388. 
[3] Bertani R.: Geothermal Power Generation in the World 2005-2010 Update Report. [in:] Proceedings World Geothermal Congress - Bali, Paper 0008, 2010 [CD].

[4] DiPippo R.: Geothermal power plants: principles, applications, case studies and environmental impact. Butterworth-Heinemann, 2007.

[5] Ryley D.: An analytical expression in terms of temperature only for optimizing the flash cycle for geothermal power plants. Geothermics, vol. 7, issue 1, 1978, pp. 9-15.

[6] Swandaru B., Pallson H.: Modeling and optimization of possible bottoming units for general single flash geothermal power plants. [in:] Proceedings World Geothermal Congress - Bali, Paper 2611, 2010 [CD].

[7] Kanoglu M., Dincer I., Rosen M.: Understanding energy and exergy efficiencies for improved energy management in power plants. Energy Policy, vol. 35, 2007, pp. 3967-3978.

[8] DiPippo R.: Exergy analysis of combined electricity and direct-heat geothermal flash steam plants. Geothermal Resources Council Transaction, no. 11, 1987, pp. 411-416.

[9] Barbacki A.: Classification of geothermal resources in Poland by exergy analysis-comparative study. Renewable and Sustainable Energy Reviews, vol. 16, 2012, pp. 123-128.

[10] Barbacki A., Pająk L.: Assesment of Possibilities of Electricity Production in Flash Geothermal System in Poland. Geomatics and Environmental Engineering, vol. 11, no. 3, 2017, pp. 17-29.

[11] DiPippo R.: A simplified method for estimating the silica scaling potential in geothermal power plants. Geothermal Resources Council - Bulletin, no. 3-9, 1985.

[12] Nugroho J.: Optimization of electrical power production from high-temperature geothermal fields with respect to silica scaling problems. United Nations University - Geothermal Training Programme, Iceland, 2011, pp. 50.

[13] Tomaszewska B., Pająk L.: 2012. Dynamics of clogging process in injection wells used to pump highly mineralized thermal waters into the sandstone structures lying under the Polish Lowlands. Archives of Environmental Protection, vol. 38, issue 3, 2012, pp. 105-117.

\section{Analityczne formuły do oceny mocy kombinowanych systemów energetycznych z separacją pary geotermalnej}

Streszczenie: Artykuł stanowi kontynuację analiz dotyczących doboru optymalnych parametrów pracy systemów geotermalnych w przypadku występowania w złożu mediów dwufazowych. Geotermalna mieszanina woda-para w jedno- lub dwustopniowym procesie rozprężania przechodzi w stan pary suchej 
napędzającej turbozespół. Porównano efektywności energetyczne systemu z jednostopniowym rozprężaniem płynu i systemów rozprężania dwustopniowego w wariancie "double-flash" i „combination single \& second" oraz systemu "single \& ORC". Wyniki uzyskanej analizy wskazują, że wśród analizowanych układów najwyższą moc wykazuje system "single \& ORC", $\mathrm{w}$ którym system $\mathrm{z}$ jednostopniowym rozprężaniem płynu współpracuje z systemem binarnym.

\section{Słowa}

kluczowe: geotermia, rozprężanie płynów geotermalnych, moc optymalna, złożone systemy geotermalne 